\title{
Komposisi Jenis Dan Zonasi Mangrove Di Kampung Gisim Kabupaten Sorong
}

\author{
Lona Helti Nanlohy ${ }^{1)}$ Azis Maruapey ${ }^{(2)}$ Yolanda Malaum ${ }^{3)}$ \\ 1) Dosen Fakultas Pertanian UMS \\ 2) Dosen Fakultas Pertanian UMS \\ 3) Mahasiswa Sarjana Fakultas Pertanian UMS
}

\begin{abstract}
ABSTRAK
Komposisi jenis merupakan formasi jenis yang berada pada suatu tempat. Penyebaran vegetasi mangrove membentuk bentuk khas yaitu membentuk zonasi sejajar garis pantai. Terdapat zonasi mangrove tertentu dari mulai arah pantai ke darat. Hal yang menarik adalah bahwa jenis-jenis mangrove yang menempati zona-zona tersebut tidak selalu sama untuk setiap daerah yang diteliti. Hal ini menunjukan adanya banyak faktor yang mengendalikan zonasi vegetasi mangrove.

Metode penelitian yang digunakan adalah penelitian survey, dengan teknik sampling sistematik menggunakan metode kombinasi antara metoda jalur dan metoda garis berpetak.

Komposisi jenis mengrove di Kampung Gisim Kabupaten Sorong terdiri dari mangrove mayor (mangrove sejati) sebanyak 5 jenis yaitu Rhizophora mucronata, Bruguiera gymnorrhiza, Bruguiera sexangula, Ceriops Tagal dan Nypa fruticans dan Mangrove minor yaitu jenis Xylocarpus granatum.

Zonasi pada lokasi penelitian secara umum dibagi menjadi 3 zona, yaitu : zona proximal, zona midle, dan zona distal. Zona proximal merupakan zona yang berbatasan langsung dengan laut dan merupakan zona dari jenis Rhizophora mucronata Zona midle adalah zona pertengahan yang terletak diantara darat dan laut, jenis yang berada zona yaitu jenis Bruguiera sexangula Bruguiera gymnorrhiza. Ceriops Tagal dan Xylocarpus granatum dan Zona distal adalah zona yang berada dibelakang zona middle yaitu jenis Nypa fruticans.
\end{abstract}

\section{PENDAHULUAN}

Mangrove adalah vegetasi hutan yang tumbuh dan dipengaruhi oleh pasang surut air laut. Mangrove tumbuh disepanjang garis pantai tropis sampai sub tropis.

Peran hutan mangrove sangat penting dalam menentukan keberadaan ekosistem kawasan pantai. Salah satu ciri tempat tumbuh hutan mangrove adalah adanya genangan air secara periodik. Komposisi jenis hutan mangrove ditentukan oleh periodisitas, lama dan tingginya genangan air, salinitas dan kondisi tanah.

Komposisi jenis mangrove merupakan formasi jenis yang terdapat dalam hutan mangrove. Komposisi jenis mangrove lebih sedikit dibandingkan dengan hutan tropika basah, namun memiliki penyebaran yang luas. Keadaan habitat sangat berpengaruh terhadap komposisi jenis mangrove. Dari beberapa hasil penelitian menunjukkan adanya variasi komposisi jenis tersebut. Menurut Bengen (2001), kompoisis hutan mangrove terdiri dari 
pohon dan semak berupa tumbuhan berbunga yaitu Avicennia, Sonneratia, Rhizophora, Bruguiera, Ceriops, Xylocarpus, Lumnitzera, Leguncularia, Aegiceras, Aegalitis,, Snaeda dan Conocarpus.

Pola penyebaran vegetasi mangrove membentuk pola khas yaitu membentuk zonasi-zonasi sejajar garis pantai. vegetasi mangrove mempunyai berbagai variasi pada lokasi yang berbeda. Selain itu jenis-jenis vegetasi mangrove tidak selalu sama untuk setiap daerah. Hal ini menunjukkan bahwa ada banyak faktor yang menentukan pola zonasi vegetasi mangrove. Adanya pengaruh faktor lingkungan yang berbeda terhadap pembentukan zonasi, diperkirakan dapat berpengaruh terhadap biota yang berasosiasi didalamnya. Terdapat zonazona mangrove tertentu dari mulai arah pantai ke darat. Hal yang menarik adalah bahwa jenis-jenis mangrove yang menempati zona-zona tersebut tidak selalu sama untuk setiap daerah yang diteliti. Hal ini menunjukan adanya banyak faktor yang mengendalikan pola zonasi vegetasi mangrove.

Hutan mangrove merupakan ekosistem yang memberikan manfaat yang besar di wilayah pesisir. Manfaat yang dapat diberikan dari hutan mangrove yaitu sebagai penyedia pakan dan tempat hidup bagi jenis-jenis fauna yang hidup di daerah perairan, penahan abrasi, penahan amukan angin, penangkal intrusi air laut, hutan mangrove juga penyedia kayu, daundaunan sebagai bahan baku obat obatan, berbagai jenis kepiting, kerang, udang, moluska yang memiliki nilai ekonomi tinggi. Selain itu, ekosistem mangrove juga berperan sebagai penyedia jasa lingkungan, seperti ekowisata

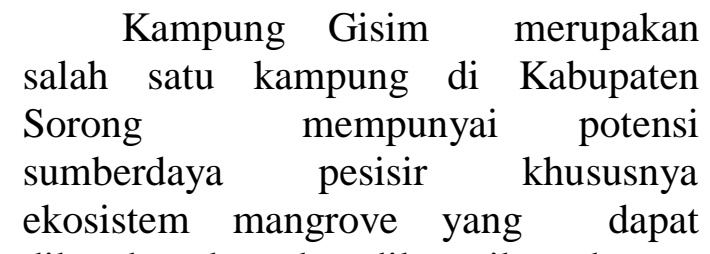
dikembangkan dan dilestarikan dengan pemanfaatan potensi yang ada secara maksimal dan lestari sangat perlu dilakukan agar hasilnya dapat dirasakan oleh masyarakat. Data sumberdaya pesisir (khususnya ekosistem mangrove) sangat diperlukan untuk mengetahui seberapa besar kemungkinan potensi pengembangan ekosistem mangrove di kabupaten Sorong, sementara ini data yang tersedia masih sedikit.

Penelitian

menyangkut

Komposisi Jenis dan Zonasi Mangrove di Kampung Gisim Kabupaten Sorong perlu dilakukan untuk mendapatkan data yang lebih akurat menyangkut keberadaan hutan mangrove.

Tujuan penelitian ini adalah: untuk mengetahui komposisi, keanekaragaman dan kekayaanjenis mangrove dan untuk mengetahui zonasi mangrove di Kampung Gizim Kabupaten Sorong. Manfaat dari penelitian ini adalah sebagai bahan masukan bagi para praktisi yang berkepentingan terhadap ekosistem mangrove.Sebagai bahan informasi kepada pemerintah daerah dalam hal ini dinas kehutanan Kabupaten Sorong dalam mengambil kebijakan untuk pemanfaatan mangrovesecara bijaksana dan lestari.Sebagai bahan acuan untuk rehabilitasi kawasan mangrove jika terjadi kerusakan.

\section{METODOLOGI PENELITIAN}

Penelitian ini dilaksanakan di Kampung Gisim Kabupaten Sorong, yang berlangsung pada bulan Agustus 2016. 
Alat yang dipergunakan pada penelitian ini adalah : meter rol, Kompas GPS, Kamera, tally sheet, alat tulis menulis dan buku panduan identifikasi mangrove. Bahan yang digunakan adalah vegetasi mangrove yang terdapat di Kampung Gisim Kabupaten Sorong,

Metode penelitian yang digunakan adalah penelitian survey, dengan teknik sampling sistematik menggunakan metode kombinasi antara metoda jalur dan metoda garis berpetak.

Prosedur penelitian yang dilaksanakan adalah :

1. Menyiapkan peta lokasi penelitian

2. Penentuan Jalur dan Petak sampel. Penentuan Jalur pengamatan dilakukan dari arah pantai ke daratan dengan lebar jalur $10 \mathrm{~m}$ dan panjang jalur disesuaikan dengan panjang lokasi penelitian (jarak hutan mangrove di tepi pantai dengan perbatasan hutan mangrove dengan daratan di belakang hutan mangrove) jumlah jalur pengamatan sebanyak 10 jalur dengan masing-masing jalur dibuat petak sampel disesuaikan dengan kondisi lapangan, sampel sehingga jumlah keseluruhan petak sampel adalah 92 petak sampel.

3. Pengamatan vegetasi mangrove

Pengukuran dilakukan sebagai berikut:

a.Semai : anakan setinggi kurang dari $1,5 \mathrm{~m}$.

b. Pancang : anakan dengan tinggi $1,5 \mathrm{~m}$ atau lebih

c. Pohon : Pohon berdiameter $10 \mathrm{~cm}$ atau lebih.

Ukuran petak untuk setiap tingkat permudaan adalah sebagaiberikut:
a. Semai: $2 \times 2 \mathrm{~m}$.
b. Pancang: $5 \times 5 \mathrm{~m}$.
c. Pohon : $10 \times 10 \mathrm{~m}$.

4. Pengumpulan data
Pengambilan data dalam penelitian ini terdiri atas data primer dan data sekunder. Data primer adalah data yang didapat pada saat melakukan penelitian dan data sekunder adalah data meliputi hasil-hasil penelitian sebelumnya, keadaan umum lokasi penelitian dan data pendukung lain yang berhubungan dengan penelitian.

Variabel penelitian ini meliputi :

a. Komposisi, keanekaragaman dan kekayaaan jenis mangrove

b. Zonasi mangrove

1. Perbedaan pengenangan

2. Jenis vegetasi mangrove yang mendominasi

3. Katagori jenis mangrove Analisis datakomposisi jenis dihitungmencakup nilai kerapatan jenis, kerapatan relatif, dominan jenis, fdominanrelatif, penutupan jenis, penutupan relatif, dan indeks nilai penting. Berdasarkan rumus dari Indrianto (2005).

a. Kerapatan

$$
(K)=\frac{\text { Jumlah Individu suatu jenis }}{\text { Luas Seluruh Petak Contoh }}
$$

Kerapatan Relatif

$$
(K R)=\frac{\text { Kerapatan suatu jenis }}{\text { Kerapatan Seluruh Jenis }} \text { X 100\% }
$$

b. Frekwensi

(F)

$$
\frac{\text { Jumlah Petakan Contoh ditemukan satu jenis }}{\text { Luas Seluruh Petak Contoh }}
$$

Frekwensi Relatif

$$
(\mathrm{KR})=\frac{\text { Frekwensi suatu jenis }}{\text { Frekwensi seluruh jenis }} \mathrm{X} 100 \%
$$

c. Dominansi
(D) $=\frac{\text { Luas bidang dasar suatu jenis }}{\text { Luas Seluruh Petak Contoh }}$

DominansiRelatif 
$(D R)=\frac{\text { Dominansi suatu jenis }}{\text { Dominan Seluruh Jenis }} X 100 \%$

d. Indeks Nilai Penting (INP) (\%)

Untuk tingkat pohon adalah

$\mathrm{INP}=\mathrm{KR}+\mathrm{FR}+\mathrm{DR}$

Untuk tingkat semai dan pancang adalah $\mathrm{INP}=\mathrm{KR}+\mathrm{FR}$

Selanjutnya keanekaragaman jenis mangrove diperoleh dengan menggunakan rumus Indeks Keanekaragaman Jenis dari Shannon dan Weaner (Ludwig dan Reynolds, 1988) yaitu :

$$
\mathrm{H}=\sum_{1=i}^{s} \text { pílog pi }
$$

Dimana :

$\mathrm{H}=$ Indeks Keanekaragaman Jenis

$P i=\mathrm{n} / \mathrm{N}$

Dimana :

$\mathrm{n}=$ Nilai penting suatu jenis

$\mathrm{N}=$ Total nilai penting seluruh jenis

Perhitungan kekayaan jenis mangrove menggunakan rumus menurut Indeks Kekayaan Jenis dari Margallef $\left(\mathrm{R}_{1}\right)$ (Indriyanto, 2006).

$$
R_{1}=\frac{S-1}{\ln (N)}
$$

Dimana :

$$
\begin{aligned}
& \mathrm{R}_{1}=\text { Indeks kekayaan Margallef } \\
& \mathrm{S}=\text { Jumlah jenis } \\
& \mathrm{N}=\text { Total seluruh jenis } \\
& \text { Zonasi mangrove akan dilihat } \\
& \text { secara visual berdasarkan perbedaan } \\
& \text { penggenangan yaitu: }
\end{aligned}
$$

1. Zona proximal

2. Zona middle

3. Zona diskal

\section{HASIL DAN PEMBAHASAN}

\section{A. Komposisi Jenis Mangrove}

Komposisi jenis tumbuhan merupakan berbagai jenis vegetasi yang berada pada suatu tempat. Komposisi jenis vegetasi merupakan daftar floristic dari jenis vegetasi yang ada dalam suatu tempat. Daftar floristic dapat dipergunakani sebagai salah satu parameter vegetasi untuk mengetahui keanekaragaman jenis vegetasi dalam komunitas

Hasil penelitian dengan menggunakan metode kombinasi yaitu menggunakan metode jalur dan garis berpetak dengan teknik sistematic sampling, maka terdapat 10 jalur pengamatan dengan lebar jalur 10 meter untuk tingkat pertumbuhan pohon, 5 meter untuk tingkat pertumbuhan pancang dan 2 meter untuk tingkat pertumbuhan semai dan panjang jalur 10 meter disesuaikan dengan lebar jalur hijau. maka terdapat 92 petak ukur dengan luas areal penelitian yaitu tingkat pohon 0,92 ha, tingkat pancang 0,23 ha dan tingkat semai 0,04 ha. Kompisisi jenis mangrove di Kampung Gisim Kabupaten Sorong dapat dilihat pada tabel 1

Tabel 1. Komposisi Jenis Mangrove di Kampung Gisim Kabupaten Sorong

\begin{tabular}{clll}
\hline No & \multicolumn{1}{c}{ Spesies } & \multicolumn{1}{c}{ Famili } & Kategori \\
\hline 1. & Bruguiera gymnorrhiza & Rhizophoraceae & Mangrove mayor \\
2. & Bruguiera sexangula & Rhizophoraceae & Mangrove mayor \\
3. & Rhizophora mucronata & Rhizophoraceae & Mangrove mayor \\
4. & Ceriops Tagal & Rhizophoraceae & Mangrove mayor \\
5. & Xylocarpus granatum & Meliaceae & Mangrove minor \\
6. & Nypa fruticans & Palmae & Mangrove mayor \\
\hline
\end{tabular}

Sumber : Data Hasil Penelitian 2016 
Tabel 1 menunjukan bahwa komposisi jenis mengrove terdiri dari mangrove mayor (sejati) sebanyak 5 jenis yang digolongkan dalam dua famili yaitu famili Rhizophoraceaedan Palmae dan mangrove minor 1 famili yaitu Meliaceae.

Hasil penelitian menunjukan bahwa jenis yang mendominasi hutan mangrove adalah jenis yng termasuk dalam kategori mangrove mayor (mangrove sejati) yaitu jenis Rhizophora mucronata dan jenis Bruguiera gymnorrhiza yang mendominasi semua tingkat pertumbuhan yaitu tingkat pohon, pancang dan semai.

Hutan Mangrove adalah satu ekosistem yang berupa mangrove mayor (mangrove sejati), mangrove minor dan mangrove asosiasi (ikutan). Mangrove mayor merupakan mangrove sejati, yakni mangrove yang hanya dapat hidup di lingkungan hutan mangrove, mempunyai bentuk-bentuk adaptif khusus ( akar nafas) dan mempunyai mempunyai kemampuan dalam mengontrol garam. Mangrove minor merupakan mangrove yang tidak terlalu berperan dalam komunitas mangrove. Mangrove asosiasi (ikutan) yaitu komponen mangrove biasanya hidup bersama tumbuhan darat.

Famili-famili yang termasuk mangrove sejati menurut Noor dkk (2006), meliputi : Avicenniaceae, Rhizophoraceae, Bombacaceae, Euphorbiaceae, Arecaceae, Myrtaceae, Lythraceae, Rubiaceae, Sonneratiaceae, Sedangkan untuk mangrove minor dan ikutan meliputi : Meliaceae, dan Pelliciera. Lecythidaceae, Guttiferae, Apocynaceae, Verbenaceae, Leguminosae, Malvaceae, Convolvula. Jenis mangrove utama yang banyak dijumpai antara lain adalah jenis
Avicennia sp.,Rhizophora sp., Bruguiera sp, dan Sonneratia sp.,

Setiap jenis mangrove yang tumbuh berhubungan dengan ;ingkungan, yaitu tempat tumbuh, pasang surut, kadar garam, fisiografi, kondisi sungai dan aktivitas manusia, setiap spesies mangrove (terutama mangrove yang termasuk dalam genus Rhizophora, Bruguiera, Sonneratia, Heritiera dan Nypa) pada kondisi ekologi yang berkaitan dengan tingkat salinitas air dan kondisi tanah, serta rezim genangan mampu membentuk zona yang khas (Kusmana, dkk, 2003).

Walsh (1974) dalam Supriyanto, (2007) menyatakan bahwa di Indonesia, substrat berlumpur ini sangat baik untuk pertumbuhan tegakan Rhizophora mucronata dan Sonneratia alba. Dari hasil penelitian menunjukan bahwa tanah yang tempat tumbuhnya mangrove adalah tanah berlumpur.

\section{B. Keanekaragaman Jenis Mangrove}

Keanekaragaman jenis dapat dinyatakan sebagai ukuran kualitatif maupun kuantitatif . Dalam ukuran kualitatif maka keanekaragaman jenis tidak lain adalah jumlah seluruh jenis yang dapat ditemukan pada suatu kondisi tertentu sehingga pada kondisi habitat tertentu yang lebih banyak jenisnya dari kondisi habitat lainnya maka dapat dianggap lebih beragam jenisnya. Sedangkan secara kuantitatif keanekaragaman jenis pada suatu kondisi habitat dapat dihitung secara matematis (Indriyanto,2006).

Hasil analisis komunitas tumbuhan diketahui dengan menganalisis vegetasi berupa kerapatan, kerapatan relatif, frekwensi, frekwensi relatif, dominasi, dominasi relatif, dan Indeks Nilai Penting dan Indeks Keanekaragaman Jenis mangrove. 
Hasil nilai Analisis vegetasi tingkat pohon pancang dan semai pada lokasi penelitian, tabel 2 sampai Tabel

4.

Tabel 2. Hasil Perhitungan Vegetasi Mangrove Tingkat pertumbuhan Pohon di Kampung Gisim Kabupaten Sorong

\begin{tabular}{ccccccccccc}
\hline No & Jenis & $\mathbf{n i}$ & $\mathbf{K}$ & $\begin{array}{c}\text { KR } \\
\mathbf{\%}\end{array}$ & $\mathbf{F}$ & $\begin{array}{c}\text { FR } \\
\mathbf{\%}\end{array}$ & $\mathbf{D}$ & $\begin{array}{c}\text { DR } \\
\text { \% }\end{array}$ & INP & H' \\
\hline 1 & Rhizophora mucronata & 71 & 77,17 & 37.2 & 0,22 & 23,81 & 337,2 & 55,61 & 116,6 & 0.16 \\
2 & Bruguiera sexangula & 22 & 23,91 & 11.5 & 0,13 & 14,29 & 25,81 & 4,26 & 30,06 & 0.10 \\
3 & Bruguera gymnorrhiza & 53 & 57,61 & 27.8 & 0,19 & 21,43 & 187,9 & 30,9 & 80,17 & 0.15 \\
4 & Ceriops Tagal & 26 & 30,43 & 14.7 & 0,19 & 21,43 & 35,39 & 5,84 & 41,92 & 0.12 \\
5 & Xylocarpus granatum & 2 & 2,17 & 1.05 & 0.06 & 7,14 & 0,36 & 0,06 & 8,25 & 0.04 \\
6 & Nypa fruticans & 15 & 16,3 & 7.9 & 0.11 & 11,9 & 19,66 & 3,24 & 23 & 0.08 \\
\hline & Jumlah & $\mathbf{1 9 1}$ & $\mathbf{2 0 7 , 6}$ & $\mathbf{1 0 0}$ & $\mathbf{0 , 9 1}$ & $\mathbf{1 0 0}$ & $\mathbf{6 0 6 , 3}$ & $\mathbf{1 0 0}$ & $\mathbf{3 0 0}$ & $\mathbf{0 . 6 6}$ \\
\hline
\end{tabular}

Sumber : Hasil Analisis Data 2016

Tabel 3. Hasil Perhitungan Vegetasi Mangrove Tingkat pertumbuhan Pancang di Kampung Gisim Kabupaten Sorong

\begin{tabular}{clccccccc}
\hline No & \multicolumn{1}{c}{ Jenis } & $\mathbf{n i}$ & $\mathbf{K}$ & $\begin{array}{c}\text { KR } \\
\mathbf{\%}\end{array}$ & $\mathbf{F}$ & $\begin{array}{c}\mathbf{F R} \\
\mathbf{\%}\end{array}$ & INP & $\mathbf{H}^{\prime}$ \\
\hline 1 & Rhizophora mucronata & 27 & 117,39 & 32,93 & 0,22 & 23,81 & 56,74 & 0,16 \\
2 & Bruguiera sexangula & 12 & 52,17 & 14,63 & 0,15 & 16,67 & 31,3 & 0,12 \\
3 & Bruguera gymnorrhiza & 24 & 104,35 & 29,27 & 0,17 & 19,05 & 48,32 & 0,15 \\
4 & Ceriops Tagal & 10 & 43,48 & 12,19 & 0,2 & 21,43 & 33,62 & 0,13 \\
5 & Xylocarpus granatum & 2 & 8,69 & 2,44 & 0,07 & 7,14 & 9,582 & 0,06 \\
6 & Nypa fruticans & 7 & 30,43 & 8,54 & 0,11 & 11,9 & 20,44 & 0,1 \\
\hline & Jumlah & $\mathbf{8 2}$ & $\mathbf{1 3 1 2}$ & $\mathbf{1 0 0}$ & $\mathbf{1 . 1 2}$ & $\mathbf{1 0 0}$ & $\mathbf{2 0 0}$ & $\mathbf{0 , 7 2}$ \\
\hline
\end{tabular}

Sumber : Hasil Analisis Data 2016

Tabel 4 . Hasil Perhitungan Vegetasi Mangrove Tingkat pertumbuhan Semai di Kampung Gisim Kabupaten Sorong

\begin{tabular}{clccccccc}
\hline No. & \multicolumn{1}{c}{ Jenis } & $\mathbf{n i}$ & $\mathbf{K}$ & $\begin{array}{c}\text { KR } \\
\mathbf{\%}\end{array}$ & $\mathbf{F}$ & $\begin{array}{c}\text { FR } \\
\mathbf{\%}\end{array}$ & INP & $\mathbf{H}^{\prime}$ \\
\hline 1 & Rhizophora mucronata & 26 & 706,52 & 28,57 & 0,22 & 24,39 & 52,96 & 0,15 \\
2 & Bruguiera sexangula & 18 & 489,13 & 19,78 & 0,13 & 14,63 & 34,41 & 0,13 \\
3 & Bruguiera gymnorrhiza & 24 & 652,17 & 26,37 & 0,19 & 21,95 & 48,32 & 0,15 \\
4 & Ceriops Tagal & 14 & 380,43 & 15,38 & 0,17 & 19,51 & 34,9 & 0,13 \\
5 & Xylocarpus granatum & 4 & 108,7 & 4,396 & 0,06 & 7,317 & 11,71 & 0,07 \\
6 & Nypa fruticans & 5 & 135,87 & 5,495 & 0,11 & 12,2 & 17,69 & 0,09 \\
\hline & \multicolumn{1}{c}{ Jumlah } & $\mathbf{9 1}$ & $\mathbf{2 4 7 2 , 8}$ & $\mathbf{1 0 0}$ & $\mathbf{0 , 8 9}$ & $\mathbf{1 9 , 5 1}$ & $\mathbf{2 0 0}$ & $\mathbf{0 , 1 6}$ \\
\hline
\end{tabular}

Sumber : Hasil Analisis Data 2016

Hasil penelitian dan analisis data pada tabel 2 menunjukan bahwa kerapatan tingkat Pohon adalah 207,6 individu/ha dan jenis yang mempunyai kerapatan relatif tertinggi adalah Rhizophora mucronata (37,17\%), ), sedangkan jenis yang mempunyai kerapatan relatif terendah adalah Xylocarpus granatum $(1,05 \%)$.

Kerapatan tingkat pancang adalah 356,52 individu/ha dan jenis yang mempunyai kerapatan relatif tertinggi 
adalah Rhizophora mucronata $(32,93 \%)$ dan kerapatan relatif terendah adalah Xylocarpus granatum (2,44\%). Sedangkan untuk kerapatan tingkat semai adalah 2472,8 individu/ha, jenis yang mempunyai nilai kerapatan relatif tertinggi adalah jenis Rhizophora mucronata $(28,57 \%)$ dan jenis dengan kerapatan relatif terendah adalah, Xylocarpus granatum (4,396\%) . Kerapatan suatu jenis mempunyai hubungan yang erat dengan persebarannya sehingga apabila suatu jenis memiliki nilai kerapatan yang tinggi berarti jenis tersebut akan menempati ruang yang lebih luas dibandingkan dengan jenis yang memiliki kerapatan yang rendah. Populasi dengan jumlah yang tinggi akan menempati suatu areal yang luas pula, artinya bahwa suatu jenis yang mempunyai kerapatan retitif yang besar mampu bersaing dengan jenis lain dan mampu menyesuaikan diri dengan kondisi lingkungannya. Menurut (Fachrul, 2007) nilai kerapatan juga dapat menggambarkan bahwa jenis dengan nilai kerapatan yang besar mampu menyesuaikan dengan kondisi dimana tumbuhan tersebut hidup. Hal ini berarti bahwa jenis Rhizophora mucronata pada semua tingkat pertumbuhan(tingkat pohon, pancang dan semai) memiliki kemampuan bersaing dan mampu menyesuaikan diri dengan kondisi lingkungan dibandingkan dengan jenis mangrove lain.

Frekuensi suatu jenis adalah perbandingan banyaknya petak yang berisi suatu jenis terhadap jumlah petak ukur seluruhnya. Sedangkan frekuensi relatif perbandingan dari frekuensi suatu jenis terhadap jumlah frekuensi seluruh jenis, biasanya frekuensi relatif dinyatakan dalam besaran persentase (Kusmana, 1997).
Hasil penelitian dan analisis data menunjukan bahwa, nilai frekuensi relatif tertinggi pada vegetasi tingkat pohon adalah jenis Rhizophora mucronata $(23,81 \%)$, sedangkan nilai frekuensi relatif terendah adalah jenis Xylocarpus granatum $(7,14 \%)$ dan jenis Frekuansi relatif tertinggi untuk vegetasi tingkat pancang adalah jenis Rhizophora mucronata (23,81\%), sedangkan frekuensi relatif terendah adalah jenis Xylocarpus granatum $(7,14 \%)$. Sedangkan frekuensi relatif tertinggi untuk vegetasi tingkat semai adalah Rhizophora mucronata $(24,39 \%)$ dan jenis dengan frekuensi relatif terendah adalah jenis Xylocarpus granatum $(7,32 \%)$

Frekuensi dipakai sebagai parameter vegetasi yang dapat menunjukan distribusi atau sebaran jenis tumbuhan dalam ekosistem. Menurut Indriyanto (2006), spesies yang distribusinya luas, memiliki nilai frekuansi yang besar. Hal ini menunjukan bahwa frekuansi dapat menggambarkan tingkat penyebaran spesies dalam suatu ekosistem. Hal ini berarti bahwa jenis Rhizophora mucronata untuk semua tingkat pertumbuhan (pohon, pancang dan semai) merupakan jenis mangrove yang distribusi atau penyebarannya luas.

Dominasi jenis adalah perbandingan antara luas bidang dasar (LBD) suatu jenis dengan luas seluruh petak ukur. Pada penelitian ini parameter dominasi yang digunakan adalah luas bidang dasar (LBD) yang merupakan suatu luasan dekat areal tanah yang dikuasai tumbuhan. Parameter dominasi dipilih karena lebih mudah dan cepat dilakukan yaitu dengan melakukan pengukuran diameter pohon pada ketinggian 1,30 meter dari permukaan tanah. Berdasarkan asumsi bahwa penampang 
melintang batang suatu pohon berbentuk lingkaran, maka Luas Bidang Dasar (LBD) dihitung dengan rumus : $\pi \mathrm{d}^{2} / 4$. Perhitungan nilai dominasi tidak dilakukan terhadap vegetasi tingkat pancang dan semai karena vegetasi tingkat pancang dan semai masih sangat kecil untuk dilakukan pengukuran diameter. Berdasarkan hasil analisis data, nilai dominasi relatif tertinggi untuk vegetasi tingkat pohon adalah jenis Rhizophora mucronata $(55,61 \%)$, sedangkan nilai dominansi relatif terendah adalah Xylocarpus granatum $(0,06 \%)$. Hal ini menunjukan bahwa vegetasi tingkat pohon jenis Rhizophora mucronata merupakan jenisyang menguasai ruang tumbuh yang ada.

Untuk mengetahui peranan suatu jenis vegetasi dalam ekosistemnya digunakan Indeks Nilai Penting (INP). Indeks Nilai Penting berguna untuk menentukan dominasi jenis tumbuhan terhadap jenis tumbuhan lain, karena dalam suatu komunitas yang mempunyai jenis yang beragam, data parameter vegetasi secara sendirisendiri dari nilai kerapatan, frekuensi dan dominasi tidak dapat menggambarkan secara menyeluruh sehingga untuk menentukan nilai penting yang berkaitan dengan struktur komunitas diperlukan perhitungan indeks nilai penting yang merupakan jumlah dari nilai kerapatan relatif, frekuensi relatif dan dominasi relatif (Fachrul, 2007). Sedangkan untuk vegetasi tingkat pancang dan tingkat semai parameter dominasinya tidak diukur, maka INP diperoleh dengan menjumlahkan kerapatan relatif dan frekuensi relatif saja. Apabila Indeks Nilai penting suatu jenis bernilai tinggi maka jenis tersebut sangat berpengaruh terhadap kestabilan ekosistem tersebut.

Berdasarkan hasil analisis data, INP tertinggi untuk vegetasi tingkat pohon adalah jenis Rhizophora mucronata $(116,6 \%)$ dan terendah adalah jenis Xylocarpus granatum $(8,25 \%)$. Untuk vegetasi tingkat pancang INP tertinggi adalah jenis Rhizophora mucronata $(56,74 \%)$ dan terendah adalah jenis Xylocarpus granatum $(9,58 \%)$. Sedangkan vegetasi tingkat semai INP tertinggi adalah jenis Rhizophora mucronata $(52,96 \%)$ dan terendah jenis Xylocarpus granatum $(11,71 \%)$. Dari Indeks Nilai Penting dapat dilihat jenis Rhizophora mucronata mendominasi vegetasi tingkat pohon, tingkat pancang dan tingkat semai pada lokasi penelitian.

Keanekaragaman jenis dapat dipakai untuk mengukur kemampuan suatu komunitas untuk tetap stabil terhadap gangguan-gangguan yang ada. Nilai keanekaragaman jenis yang tinggi biasanya ditunjuk sebagai petunjuk kestabilan lingkungan. Makin tinggi nilai kenekaragaman jenis suatu jenis maka makin stabil kondisi ekosistem tersebut. Berdasarkan hasil analisis data dengan menggunakan Indeks Shannon dan Wearen, diperoleh nilai Indeks Keanekaragaman (H') untuk vegetasi tingkat pohon adalah 0,66 , vegetasi tingkat pancang 0,72 dan vegetasi tingkat semai 0,16 . Nilai ini menunjukan bahwa Indeks keanekeragaman jenis $\mathrm{H}<1$ berarti Keanekaragaman jenis mangrove memiliki nilai keanekaragaman jenis rendah, hal ini disebabkan jenis mangrove yang terdapat di lokasi penelitian tergolong sedikit karena hanya terdapat 6 jenis mangrove. Menurut Soegianto (1994) dalam Indriyanto (2006), jika suatu komunitas dikatakan memiliki keanekaragaman jenis yang tinggi jika komunitas tersebut tersusun oleh banyak jenis dan sebaliknya keanekaragaman rendah jika komunitas itu tersusun oleh sedikit jenis 
dan jika hanya ada sedikit spesies yang dominan.

\section{Kekayaaan Jenis Mangrove}

Kekayaan jenis adalah jumlah jenis (spesies) dalam suatu komunitas. Kekayaan jenis besar jika semakin banyak jumlah jenis yang ditemukan. Hasil penelitian menunjukkan, indeks kekayaan jenis pada tingkat pohon $(35,22)$ tingkat pancang $(17,23)$ dan tingkat semai $(18,68)$, jika semakin luas suatu lokasi penelitian maka akan semakin besar pula indeks kekayaan jenisnya, karena akan semakin banyak jenis yang ditemukan dan semakin banyak pula jumlah individu dari jenis tersebut.

\section{Zonasi Mangrove}

1. Perbedaan Pengenangan

Zonasi mangrove terbentuk karena adanya pengaruh dari beberapa faktor lingkungan. Menurut Bengen dan Dutton (2002) dalam Northcote dan Hartman (2004) faktor-faktor yang mempengaruhi terbentukny zonasi hutan mangrove adalah salinitas, toleransi terhadap ombak dan angin, toleransi terhadap lumpur (substrat) dan frekuensi genangan air.

\section{KESIMPULAN}

ini adalah :

1. Komposisi jenis mengrove terdiri dari mangrove mayor (mangrove sejati) sebanyak 5 jenis yaitu Bruguiera gymnorrhiza Bruguiera sexangula, Rhizophora mucronata Ceriops Tagal, Nypa fruticans dan Mangrove minor yaitu jenis Xylocarpus granatum.

2. Nilai Indeks Keanekaragaman (H') untuk vegetasi tingkat pohon adalah 0,66 , vegetasi tingkat pancang 0,72
Zonasi vegetasi yang terbentuk pada Jalur 1 sampai dengan jalur 5 adalah Rhizophora mucronata, Bruguiera gymnorrhiza dan Bruguiera sexangula Ceriops Tagal dan Xylocarpus granatum dan Nypa fruticans.

Pada lokasi penelitian secara umum dibagi menjadi 3 zona, yaitu : Zona proximal, Zona midle, dan Zona distal. Zona proximal merupakan zona yang berbatasan langsung dengan laut dan merupakan zona dari jenis Rhizophora mucronata Zona midle adalah zona pertengahan yang terletak diantara darat dan laut, jenis yang berada zona yaitu jenis Bruguiera sexangula Bruguiera gymnorrhiza. Ceriops Tagal dan Xylocarpus granatum dan Zona distal adalah zona yang paling jauh dari laut yaitu jenis Nypa fruticans.

Adanya pola zonasi yang berbedabeda disebabkan oleh faktor-faktor antara lain bentuk permukaan, kisaran pasang surut, pengaruh gelombang, salinitas, substrat dan interaksi faktpr biotik dan abiotik. Faktor lingkungan yang mengontrol zonasi mangrove adalah : kondisi pasang surut, tipe tanah, kadar garam dan penyinaran surya

dan vegetasi tingkat semai 0,16 . Nilai ini menunjukan bahwa Indeks keanekeragaman jenis $\mathrm{H}^{\prime}<1$, berarti Keanekaragaman jenis mangrove memiliki nilai keanekaragaman jenis rendah sedangkan nilai kekayaan jenis pada tingkat pohon $(35,22)$ tingkat pancang $(17,23)$ dan tingkat semai $(18,68)$.

3. Zonasi pada lokasi penelitian secara umum dibagi menjadi 3 zona, yaitu : Zona proximal, Zona midle, dan Zona distal. Zona proximal merupakan zona yang berbatasan langsung dengan laut dan merupakan 
zona dari jenis Rhizophora mucronata Zona midle adalah zona pertengahan yang terletak diantara darat dan laut, jenis yang berada zona yaitu jenis Bruguiera sexangula Bruguiera gymnorrhiza. Ceriops Tagal dan Xylocarpus granatum dan Zona distal adalah zona yang terletak dibelakang Zona middle yaitu jenis Nypa fruticans.

\section{DAFTAR PUSTAKA}

Arief, A. 2003. Hutan Mangrove :

Fungsi dan Manfaatnya. Penerbit Kanisius. Yogyakarta.

Bengen, D. G. 2000. Teknik pengambilan contoh dan analisis data biofisik sumberdaya pesisir. PKSPL-IPB. Bogor.

Bengen. D. G. 2001. Pedoman Teknis Pengenalan dan Pengelolaan Ekosistem

Mangrove. Pusat Kajian Sumberdaya Pesisir dan Lautan. Institut Pertanian Bogor. Bogor.

Bengen, D. G. 2004. Pedoman teknis: Pengenalan dan pengelolaan ekosistem mangrove. PKSPLIPB. Bogor.

Dahuri, R, J. Rais, S. P. Ginting dan M. J. Sitepu. 1996. Pengelolaan SumberdayaWilayah Pesisir dan Lautan Secara Terpadu. Penerbit Pradya Paramita.Jakarta

Dahuri, R. 2003. Keanekaragaman Hayati Laut : Aset Pembangunan Berkelajutan Indonesia. Penerbit Gramedia Pustaka Utama. Jakarta

Darsidi, A. 1986. Perkembangan pemanfaatan hutan mangrove di Indonesia. Prosiding Seminar II Ekosistem Mangrove, Denpasar, Bali. 5-8 Agustus 1986.

Indriyanto. 2006. Ekologi Hutan. Penerbit Bumi Aksara. Jakarta.

Istomo. 1992. Tinjauan ekologi mangrove dan pemanfaatannya di
Indonesia. Lab. Ekologi Hutan. Jurusan Manajemen Hutan, Fakultas Kehutanan, IPB. Bogor.

Kitamura, S., C. Anwar, A. Chaniago dan S. Baba. 1997. Buku panduan mangrove di Indonesia. ISME. Denpasar. Indonesia.

Kusmana, C. 1997. Manajemen hutan mangrove Indonesia. Lab Ekologi Hutan. Jurusan Manajemen Hutan, Fakultas Kehutanan, IPB. Bogor.

Kusmana, C, S. Wilarso, I. Hilwan, P. Pamoengkas, C. Wibowo, T. Tiryana, A.

Triswanto, Yunaswi dan Hamzah. 2003. Teknik Rehabilitasi Mangrove. Fakultas Kehutanan. Institut Pertanian Bogor. Bogor.

Munawar. 1995. Studi Zonasi Vegetasi Mangrove di Teluk Gilimanuk Taman Nasional Bali Barat Propinsi Bali. (Tesis). Universitas Gajah Mada. Yogyakarta.

Nontji, A. 1987. Laut nusantara. Djambatan. Jakarta.

Nybakken, J. W. 1988. Biologi Laut : Suatu Pendekatan Ekologis. Penerbit Gramedia. . Jakarta.

Nybakken, J. W. 1992. Biologi Laut : Suatu pendekatan ekologis (Terjemahan oleh : M. Eidman, Koessoebiono dan D. G. Bengen, M. Hutomo dan Sukristijono). Penerbit PT. Gramedia. Jakarta. Indonesia.

Poedjirahajoe, E. 1995. Peranan Akar Bakau Sebagai Penyangga Kehidupan Biota Laut Di Kawasan Rehabilitasi Mangrove Pantai Pemalang Jawa Tengah. (Tesis). Universitas Gajah Mada. Yogyakarta.

Poedjirahajoe, 2007. Ekologi Mangrove. Bahan Kuliah. Program Sudi IlmuKehutanan. Sekolah Pasca Sarjana. 
Universitas Gajah Mada. Tjardhana dan E. Purwanto. 1995.

Yogyakarta.

Romomohtarto, K, S. Juwana. 2007.

Biologi Laut : Ilmu Pengetahuan

TentangBiota Laut. Penerbit

Djambatan. Jakarta.
Hutan Mangrove Indonesia. Duta

Rimba.

Jakarta 